\title{
Characterization of a non-industrial pig production system: the case of Bísaro breed
}

\author{
Gustavo Paixão $^{1^{*}}$ (D), Alexandra Esteves ${ }^{1}$ (D), Rita Payan-Carreira ${ }^{1}$ \\ ${ }^{1}$ Universidade de Trás-os-Montes e Alto Douro, Animal and Veterinary Research Centre, Vila Real, Portugal.
}

\begin{abstract}
This study aimed to characterize the current production system of the Bísaro pig breed. Between February and April 2017, 194 questionnaires covering different aspects of the system were sent as a disclosed identity mail survey. A response rate of $31.4 \%$ was obtained. The typical Bísaro farmer is 46 years old, male, has five years of experience rearing pigs, and has a secondary or higher education degree. Piglets represented the majority of animals sold for slaughter (91.1\%) and constituted $41.1 \%$ of total Bísaro meat produced with 343 tons. The majority of producers differentiate feed per production group (79.3\%) and allow grazing (73.7\%). Feeding is usually complemented with own-farm crops (94.7\%). Traditional housing system remains the most common (52.6\%), but free-range camping systems had a considerable expression (40.4\%). All year-around farrowing system (91.2\%) without heat detection (65.5\%) and limited use of artificial insemination (12.5\%) characterized the reproduction management. Males are commonly castrated at 29 days, before weaning at 35 days. Categorization of farms showed some significant differences: smallholders $(n=33)$ belonged to a single producer, had family-based work, and reproductive management was predominantly less strict; non-industrial medium-sized holdings $(n=26)$ operated as commercial-based farms with larger production, greater farm areas, and more advanced technology. Although the survey demonstrated variability within farms, Bísaro production system was characterized, and two different types of farms were identified. This study provided the tools needed to discuss and revise some management practices, mainly those that revealed noncompliance with EU regulations, to enhance consistency of Bísaro products.
\end{abstract}

Key Words: livestock, native breed, pig production, production system, swine

\section{Introduction}

Bísaro pig breed (BP) is a native Portuguese breed descending from the Celtic line (Santos e Silva et al., 2000a). It is characterized by a slow growth rate, low feed conversion, bad conformation, moderate quantity of subcutaneous fat, and excellent meat quality (Ramos et al., 2003). Traditionally reared in the northern interior of Portugal for domestic consumption, BP population declined following the industrialization of the pork sector and subsequent introduction of leaner breeds (Santos e Silva et al., 2000b; Santos Silva and Tirapicos Nunes, 2013). It has been suggested that crossbreeding with the newly introduced exotic breeds might have occurred (Ramos et al., 2003; Carolino et al., 2007) until BP was officially recognized and catalogued as a protected breed in danger

Received: December 21, 2017

Accepted: April 3, 2018

*Corresponding author: gus.paixao@utad.pt

Copyright (c) 2018 Sociedade Brasileira de Zootecnia. This is an Open Access article distributed under the terms of the Creative Commons Attribution License (http://creativecommons.org/licenses/by/4.0/), which permits unrestricted use, distribution, and reproduction in any medium, provided the original work is properly cited. of extinction (Fernandes et al., 2010). Nevertheless, it is believed that the breed still holds high levels of genetic variability and clear breed differentiation representing an attractive reservoir of genetic diversity (Vicente et al., 2008). Nowadays, and thanks to producers, researchers, and producers' organization, BP is known for producing highquality smoked-cured meats and holds multiple registered standardized quality products (Araújo et al., 2016).

Despite the undeniable potential value associated with this breed, very little is known about its unique production system. A single scientific report (Carvalho, 2000) described BP production system as semi-extensive, smallholding type with few technologic resources. The animals were mainly kept indoors in traditional piggeries with access to outdoor spaces. Nevertheless, there is an important historical and dimensional knowledge gap regarding this particular breed and its production system.

This study was conducted as an in-depth crosssectional investigation to improve our understanding of current BP production tendencies. Grouping farms into clusters can be one of the key aspects to identify practices that should be improved (Gelasakis et al., 2017). As many other traditionally pig rearing systems based on rural areas 
across the world, BP production represents a major income to the local community, making this activity vital for the economic development of these rural regions (Riedel et al., 2014). The knowledge gathered in this study can set up the foundations to develop appropriate and sustainable strategies to improve the Bísaro pig and other autochthonous breeds reared in traditional systems.

\section{Material and Methods}

The study was conducted between February and April 2017 as a disclosed identity mail survey to all producers registered in the National Bísaro Pig Producer Association (ANCSUB). Farms are concentrated in the northeast and dispersed to coastal and southern areas, in a lesser proportion, covering 11 of the 17 mainland Portugal districts (Figure 1). Notwithstanding, the majority of farms are located at a high altitude (over $400 \mathrm{~m}$ above sea level), with the topography ranging from inland plateaus to semimountainous and mountainous areas. The survey included all the production regions. At the time of the study, there were 6396 and 631 registered breeding sows and boars, respectively, from 215 producers. Only 194 producers had at least one registered animal on the farm, being considered as active, and, therefore, composed the study population. A

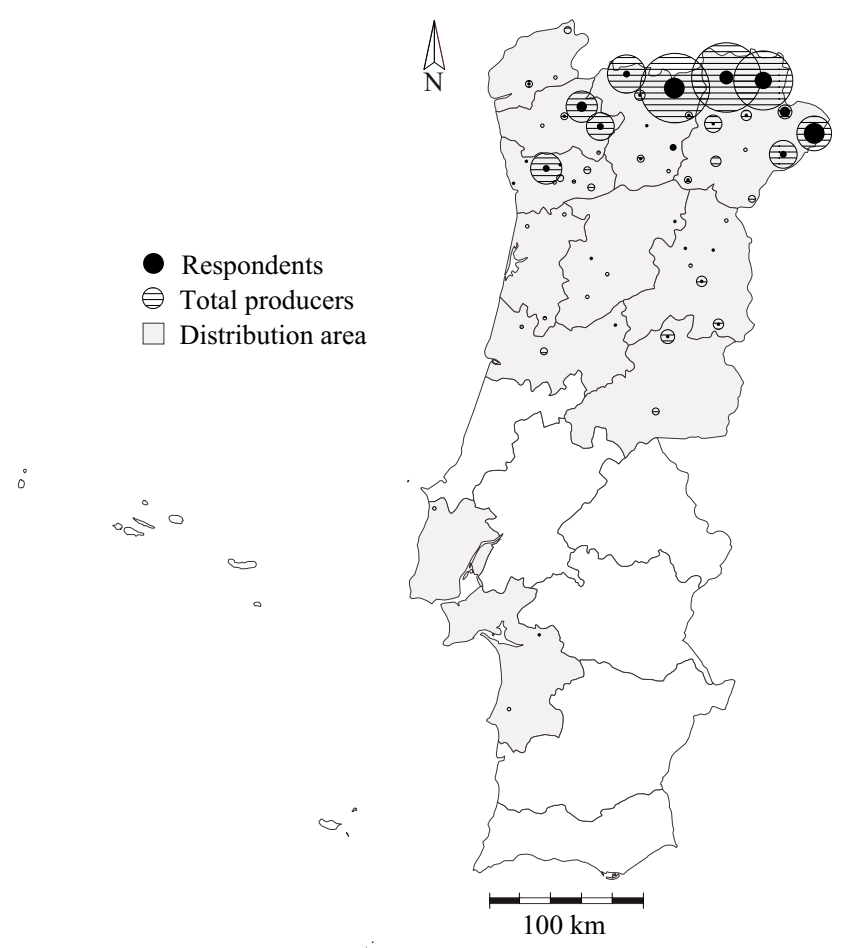

Size of circles represents proportion of respondents/total producers and shows the approximate location of farms.

Figure 1 - Geographical distribution of Bísaro pig farms, by district. total of 194 questionnaires were sent out, and 61 answered questionnaires were returned. Of these, two questionnaires were excluded from the analysis for missing data. In sum, 59 valid answered questionnaires were available for analysis.

The questionnaires were sent out along with a cover letter and returned by mail as a free-of-charge self-response envelope. Even though cost-effectiveness of web surveys could have been appealing, higher response rates are normally achieved by mail surveys (Shih and Fan, 2007; Hardigan et al., 2012). Furthermore, the allegedly elderly and rural study population, with limited technological knowledge, enhanced the choice of a mail-based survey. The questionnaire consisted of six pages, in a total of 40 questions, covering five main topics: Farm Manager/ Owner Profile, Farm Profile, Feeding, Housing, and Reproduction. It totalized 40 questions comprising closed $(\mathrm{n}=25)$ and short semi-closed $(\mathrm{n}=15)$ questions in a simple, clear format to minimize confusion and maximize response accuracy. The first section was composed by farm manager demographic questions such as gender, age, experience as a pig farmer, and level of education. The second part aimed to characterize management and organizational aspects of the farm: phase of production, production estimates per year, use of other pig breeds, purpose and structure of the farm, and whether there is a meat-processing unit associated with the farm. The third topic included questions related to animal feeding: whether and how much use of complete ration, inclusion of other types of feed, diet supplementation and differentiated feeding, automatic feeding and drinking systems, and grazing regimes. The fourth section asked for information regarding housing and management: housing system (for which three types were considered: the industrial housing system, represented by large sheds without outdoor space, and the traditional, represented by piggeries with smaller sheds and outdoor space, while camping corresponded to free-range outdoor cabins), maternity system, outdoor and indoor areas, automated ventilation, and segregation within production groups. The fifth section comprised basic questions on reproductive management (the use of heat detection, the main breeding method, age at first service, farrowing planning, age at weaning, use of voluntary waiting period, castration), as well as on basic reproductive traits, such as average litters per year/lifetime, longevity of boars, and the use of crossbreeding. The questionnaire was translated from Portuguese to English and is available from the corresponding author upon request.

The database was developed using Microsoft Access 2013 (Microsoft Corporation, Redmond, WA, USA, 2013). Closed multiple-choice answers were converted into 
categorical variables. Answers from semi-closed questions (quantitative data) were introduced as continuous variables. Access to pedigree and database of producers was granted to the authors by ANCSUB to collect animal population and farm location data.

Farms were divided into categories according to their number of livestock units (LSU). Livestock units are European reference units, which facilitate the aggregation of livestock from various species and age as per convention. In pigs, breeding animals over $50 \mathrm{~kg}$ represent $0.5 \mathrm{LSU}$, piglets under $20 \mathrm{~kg}, 0.027 \mathrm{LSU}$, and all other pigs over three months old, 0.3 LSU. Smallholders (SH) include small farms with less than 15 LSU, whereas non-industrial medium-sized holdings (MS) comprise farms with 15 or more LSU. Industrial farms represent holdings with more than 260 LSU, with animals being exclusively reared on intensive systems.

Statistical analysis was conducted in JMP 7 (SAS Institute Inc., Cary, NC, 2007). Descriptive analysis was first performed to characterize the whole population trends. Categorical variables were presented as absolute and relative frequencies for both farm types, and the continuous variables were described as means \pm SEM, median, range, or interquartile range. These variables were analyzed at the level of farm category, and group differences were identified using the chi-squared test for categorical variables. The Shapiro-Wilk test was used to assess normality for continuous variables of interest. For normally distributed data, farm differences were compared using ANOVA, whereas the Wilcoxon Rank test was used for non-normal distributed data. P-values (SH vs. MS) represent the probability of a farm category (independent variable) and the study parameter (depend variable) being independent $(\alpha=0.05)$.

The estimated annual production and the annual meat production estimate were calculated, respectively, by the following equations: annual average number of animals sold per LSU $\times$ total LSU, and estimated annual production $\times$ carcass average weight. The average carcass weights considered for piglets, growers, and finishers were 6, 67, and $120 \mathrm{~kg}$ respectively (Costa, 2015; Fernandes et al., 2015). Average stocking density per breeding animal was estimated from the quotient between the values of indoor areas, obtained from individual responses, and the registered breeding stock in ANCSUB database.

\section{Results}

A $31.1 \%$ response rate $(61 / 194)$ was obtained, and $59 / 194$ of farmers $(30.4 \%)$ returned questionnaires suitable for analysis. The categorization of farms resulted in 36 SH and 23 MS farms. No industrial farms were identified. Men represented the majority of farm managers (64.9\%), and this fact was more evident on MS farms. On average, farm managers were 47 years old and had an average of eight-year experience rearing pigs. Furthermore, $84.5 \%$ of producers had finished secondary education (Table 1).

Figure 2 displays the estimated annual BP production, considering the average number of animals sold for slaughter each year per farm. Piglets for slaughter represented the vast majority of animals intended for slaughter per farm per year $(91.1 \%)$. The estimated annual production was 834 tons of meat and 62692 slaughtered animals. Only $3.7 \%$ of the animals sold for slaughter are mature pigs intended for the cured meat market, representing an estimate of 275 tons of meat going for processing.

Almost all respondents (86.4\%) declared rearing exclusively BP and only $6.9 \%$ affirmed crossing BP with other breeds. All farmers that responded using other swine breed claimed using commercial exotic breeds; Pietran had the largest number of answers $(n=5)$. On most MS farms (61.5\%), pig production represented the main income for producers, whereas $21.2 \%$ of SH producers claimed to rear BP for recreational or traditional purposes. Within farm organization, significant differences between $\mathrm{SH}$ and MS farms were found in accounting $(\mathrm{P}<0.05)$ and workforce $(\mathrm{P}<0.05)$. Non-industrial medium-sized holdings farms were organized mainly as a one-person business with organized accounting (41.7\%), while SH were organized as single producers with no business/enterprise structure (64.3\%). Most of the SH workforce was composed of the producer and his family $(78.6 \%)$; contrarily, most of the MS admitted having paid workers (66.7\%). A fifth of the respondents had an associated meat-processing unit, which were predominantly classified as micro establishments.

Almost all BP producers (94.7\%) claimed using feed other than commercial ration and $24.6 \%$ admitted not using any ration at all. Of other feed used, cereals (92.6\%), vegetables $(90.7 \%)$, and tubers $(88.9 \%)$ were the main alternative or complement feed to commercial ration. Almost a fifth of the producers (22.2\%) admitted using domestic food scraps to feed their animals (Figure 3). The majority of the respondents (79.3\%) stated they differentiate feed between production groups. The existence of automated feeding and drinking systems depended on farm type $(\mathrm{P}<0.05)$, and all MS farms had at least one automated system. Grazing did not differ between farm types, and $73.7 \%$ of all farmers claimed their animals have access to pasture. Of those, boars $(88.4 \%)$, pregnant sows $(87.8 \%)$, and dry sows $(78.7 \%)$ were the most pointed groups to be 
Table 1 - Descriptive statistics of farm manager and farm profiles by type of farm

\begin{tabular}{|c|c|c|c|c|c|c|}
\hline & Units $^{1}$ & $\mathrm{R}$ & Total & Smallholders & Medium-sized farms & P-value ${ }^{2}$ \\
\hline \multicolumn{7}{|l|}{ Farm manager profile } \\
\hline Gender & & 57 & & & & 0.261 \\
\hline Male & $\mathrm{n}(\%)$ & & $37(64.9)$ & $19(57.6)$ & $18(75.0)$ & \\
\hline \multirow[t]{2}{*}{ Age (years) } & & 54 & & & & 0.528 \\
\hline & Mean \pm SEM & & $47.2 \pm 1.6$ & $46.3 \pm 2.1$ & $48.4 \pm 2.5$ & \\
\hline \multirow{2}{*}{ Experience (years) } & Mean \pm SEM & & $7.6 \pm 1.0$ & $8.6 \pm 1.6$ & $8.1 \pm 1.1$ & \\
\hline & Median $[1 \mathrm{Q}, 3 \mathrm{Q}]$ & & $5[4,10]$ & $5[1,40]$ & $7[2,25]$ & \\
\hline Level of education & & 58 & & & & 0.643 \\
\hline Primary education & $\mathrm{n}(\%)$ & & $9(15.5)$ & $4(12.1)$ & $5(20.0)$ & \\
\hline Secondary education & $\mathrm{n}(\%)$ & & $24(41.4)$ & $15(45.5)$ & $9(36.0)$ & \\
\hline Higher education & $\mathrm{n}(\%)$ & & $25(43.1)$ & $14(42.4)$ & $11(44.0)$ & \\
\hline \multicolumn{7}{|l|}{ Farm profile } \\
\hline \multirow{2}{*}{ Piglets at weaning } & Mean \pm SEM & & $323.7 \pm 46.3$ & $158.3 \pm 20.4$ & $535.3 \pm 86.1$ & \\
\hline & Median $[1 \mathrm{Q}, 3 \mathrm{Q}]$ & & $212[103,400]$ & $150[62,251]$ & $450[256,750]$ & \\
\hline \multirow[t]{3}{*}{ Growers - fresh meat } & & 57 & & & & 0.356 \\
\hline & Mean \pm SEM & & $18.5 \pm 15.9$ & $3.3 \pm 1.4$ & $37.9 \pm 36.3$ & \\
\hline & Median $[1 \mathrm{Q}, 3 \mathrm{Q}]$ & & $0[0,2]$ & $0[0,3]$ & $0[0,0]$ & \\
\hline \multirow[t]{3}{*}{ Finishers - cured meat } & & 57 & & & & 0.058 \\
\hline & Mean \pm SEM & & $13.0 \pm 4.9$ & $2.9 \pm 0.7$ & $25.9 \pm 10.8$ & \\
\hline & Median $[1 \mathrm{Q}, 3 \mathrm{Q}]$ & & $2[0,10]$ & $2[0,5]$ & $5[0,23]$ & \\
\hline \multicolumn{7}{|l|}{ Annual production for sale ${ }^{3}$} \\
\hline \multirow[t]{2}{*}{ Breeding animals } & & 57 & & & & 0.092 \\
\hline & Mean \pm SEM & & $6.6 \pm 3.6$ & $2.2 \pm 1.6$ & $12.3 \pm 8.0$ & \\
\hline Crossbreed & & 58 & & & & 0.620 \\
\hline Yes & $\mathrm{n}(\%)$ & & $4(6.9)$ & $3(9.4)$ & $1(3.8)$ & \\
\hline No & $\mathrm{n}(\%)$ & & $54(93.1)$ & $29(90.6)$ & $25(96.2)$ & \\
\hline Purpose of rearing pigs & & 59 & & & & 0.232 \\
\hline Primary income & $\mathrm{n}(\%)$ & & $29(49.2)$ & $13(39.4)$ & $16(61.5)$ & \\
\hline Secondary income & $\mathrm{n}(\%)$ & & $20(33.9)$ & $13(39.4)$ & $7(26.9)$ & \\
\hline Other & $\mathrm{n}(\%)$ & & $10(16.9)$ & $7(21.2)$ & $3(11.5)$ & \\
\hline Accounting & & 52 & & & & 0.035 \\
\hline Single producer & $\mathrm{n}(\%)$ & & $25(48.1)$ & $18(64.3)$ & $7(29.2)$ & \\
\hline One-person business & $\mathrm{n}(\%)$ & & $17(32.7)$ & $7(25.0)$ & $10(41.7)$ & \\
\hline Society/group & $\mathrm{n}(\%)$ & & $10(19.2)$ & $3(10.7)$ & $7(29.2)$ & \\
\hline Workforce & & 49 & & & & 0.006 \\
\hline Self-employed/family work & $\mathrm{n}(\%)$ & & $29(59.2)$ & $22(78.6)$ & $7(33.3)$ & \\
\hline Some paid work & $\mathrm{n}(\%)$ & & $16(32.7)$ & $5(17.9)$ & $11(52.4)$ & \\
\hline All paid work & $\mathrm{n}(\%)$ & & $4(8.2)$ & $1(3.6)$ & $3(14.3)$ & \\
\hline Meat processing unit & & 59 & & & & 0.187 \\
\hline Yes & $\mathrm{n}(\%)$ & & $11(18.6)$ & $4(12.1)$ & $7(26.9)$ & \\
\hline No & $\mathrm{n}(\%)$ & & $48(81.4)$ & $29(87.9)$ & $19(73.1)$ & \\
\hline
\end{tabular}

$\mathrm{R}$ - number of respondents; SEM - standard error of the mean.

${ }^{1}$ Normally distributed continuous variables are presented as mean $\pm \mathrm{SEM}$, median, min and max. Non-normal data are presented as mean $\pm \mathrm{SEM}$, median, first and third quartiles.

${ }^{2} \mathrm{P}$-value resulting from the independency test between smallholders and medium-sized farms.

${ }^{3}$ The annual production for slaughter corresponds to the number of animals sold for slaughter in a year time, whereas annual production for sale corresponds to those sold, in life, to other producers. 


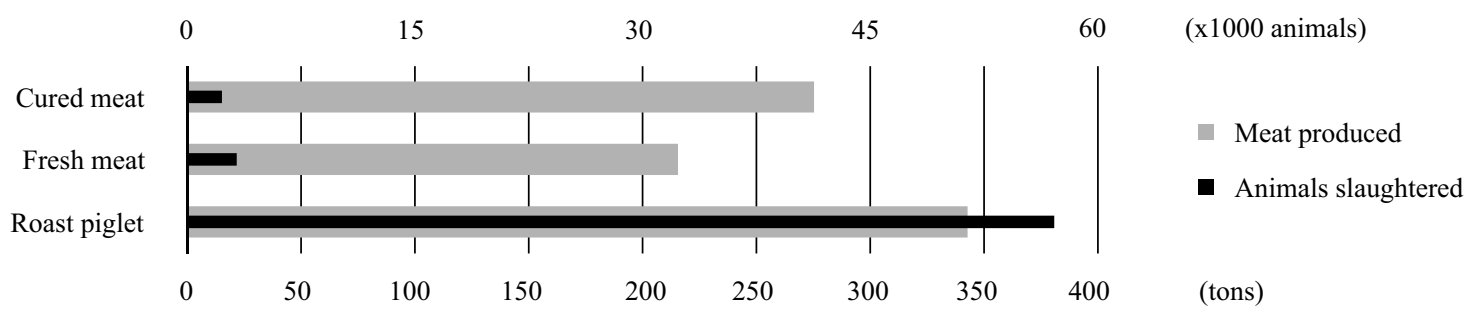

Figure 2 - Estimate of total Bísaro annual production (tons) based on the number of animals sold for slaughter (x1000).

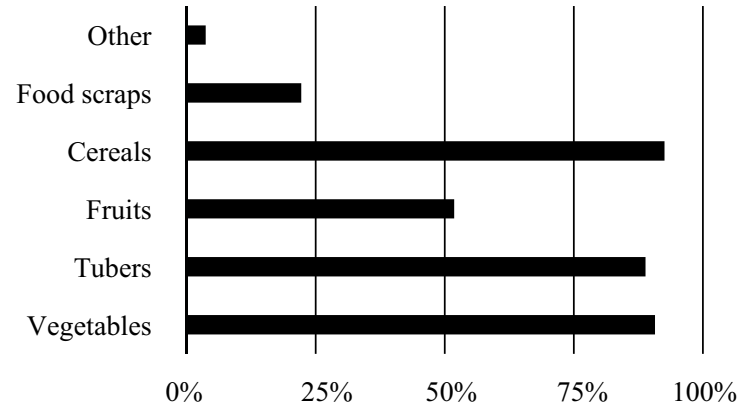

Figure 3 - Complement feed to commercial ration included in Bísaro production - percentage of respondents that use or include feed other than commercial ration in their animal diet, by class $(n=57)$.

grazing at part or full-time. Conversely, lactating sows $(91.3 \%)$ and piglets $(76.1 \%)$ were those mostly identified having diet supplementation (Figure 4).

Over half of the producers interviewed characterized their housing system as traditional (52.6\%), having a small shed or traditional piggery with outdoor pens; however, almost another half (40.4\%) described it as being fully outdoor, on a camping system. Few producers reported having forced ventilation in the animal building (18.2\%), but MS farms were more likely to have this equipment $(\mathrm{P}<0.05)$. Most of the producers admitted they separate animals by production group ( $84.5 \%$ ); however, few seem to separate by gender (28.3\%); furthermore, 53 days was the average age when animals were separated by gender. Maternity systems did not differ between farm categories $(\mathrm{P}>0.05)$. On the other hand, maternity systems were dependent on housing systems $(\mathrm{P}<0.05)$ with almost a third of producers allowing farrowing to happen in outdoor cabins $(26.9 \%)$.

Most producers claimed their animals have access to outdoor areas $(87.9 \%)$. The outdoor areas ranged from $56 \mathrm{~m}^{2}$ to 40 ha (median $=1$ ha; IQR: $0.2-2.8$ ). The average outdoor area was larger in MS than in SH farms, although no significant differences were registered. In general, MS farms had also larger indoor areas compared with $\mathrm{SH}$ $(\mathrm{P}<0.05)$. The estimated average breeding stock density was $16.8 \pm 2.3 \mathrm{~m}^{2}$ per breeding stock.
Approximately one-third (34.5\%) of the interviewed producers assumed they perform heat detection on their breeding sows. All of the producers admitted using natural mounting with own boar; few producers $(12.5 \%)$ claimed using artificial insemination (AI); and only one (1.8\%) reported breeding using boars from another Bísaro producer. Most of them introduced sows to boars at eight months of age (IQR: 6-15) and wean piglets at 35 days (IQR: 20-60). Few BP producers $(15.8 \%)$ affirmed to voluntarily wait to breed sows again after weaning, which was more evident in $\mathrm{SH}(\mathrm{P}<0.05)$; three-quarters of these producers claimed to wait, on average, until the second standing heat after weaning. Moreover, fewer farmers claimed planning farrowing to happen in certain periods of the year $(8.8 \%)$. The majority of producers $(61.7 \%)$ assumed surgically castrating males, usually just before weaning (median: 29 days; IQR: 4-75). On average, BP producers that responded to the survey believe having two litters per sow annually and eight in their productive lifetime.

\section{Discussion}

The data collected in this study came from almost a third of the population of producers and, therefore, represent a good overview of the practices used in Bísaro production nowadays. Categorization of BP farms based on hierarchical clusters resulted in artificial and disparate groups regarding the number of farms included. Despite the difficulties in grouping a large number of producers by their production systems, categorization based on LSU constituted a better representation of the BP reality. Smallholders belonged to single producers and had family-based work; automation was absent, and production regime was predominantly less strict. Non-industrial medium-sized holdings farms were commercial-based farms, with larger production, greater farm areas, and were technologically more advanced.

Younger, less experienced, and more educated farmers resumed the demography of producers. More than half of the producers were under 50 years old. Similar results were found by Relun et al. (2015) in a study about the Corsican 


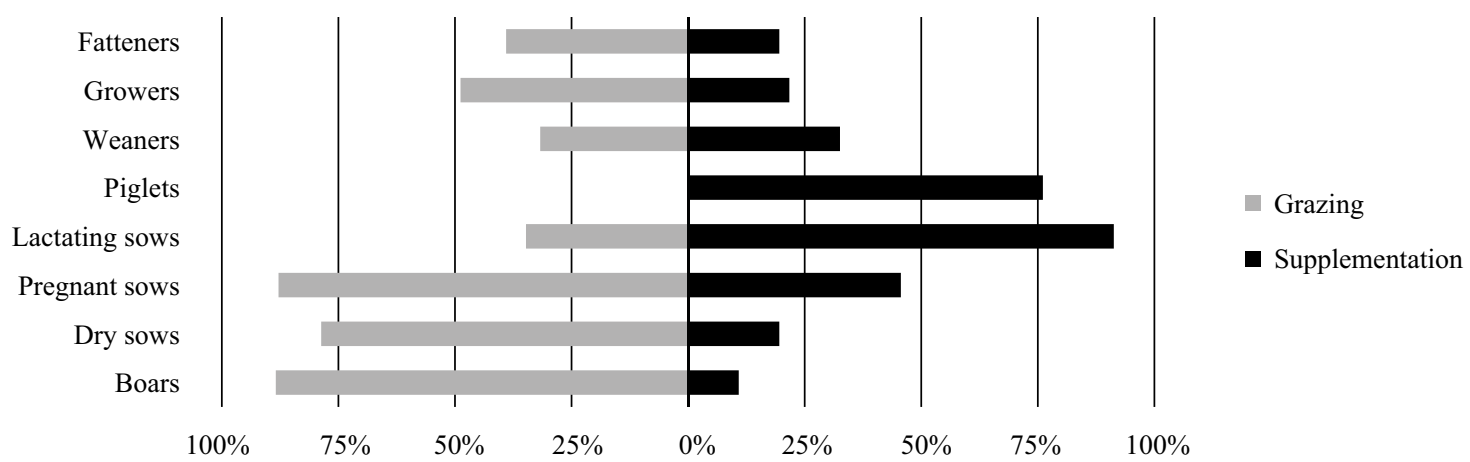

Figure 4 - Grazing and diet supplementation in Bísaro production - percentage of producers that contemplate grazing and supplementation in their feeding regimes, by production group $(n=57)$.

pig production, but are contrary to older descriptions from a Bísaro technical report (Outor-Monteiro et al., 2005). Experience in rearing pigs was, however, significantly lower when compared with other survey-based studies regarding pig production in Asia and Oceania (Alawneh et al., 2014; Leslie et al., 2015; Schembri et al., 2015). Controversially, most of the respondents held a higher education degree, which could be partly explained by the EU financial aid for young farmers to establish new holdings of the last decades. This phenomenon is truly decisive given the higher European funding for endangered breeds, like the BP, compared with current industrial hybrids. It also explains why so many of these smallholders (39.4\%) can live primarily sustained by this activity. Surprisingly, some smallholders also stated having some paid work (17.9\%), mainly seasonal-related with animal handling and agricultural labour spikes across the year.

Although a previous field study (Carvalho, 2000) described smoked-cured meat as the majority of BP production, our results showed a considerable higher number of animals sold for roast piglet, usually after weaning (10-12 kg BW) compared with animals slaughtered for fresh or cured meat. In fact, our estimate of BP meat production per year follows the same trend, in which piglets were the most representative carcass weight produced compared with other classes for slaughter. Furthermore, and contrary to existing technical reports from ANCSUB (2007), a third of the respondents reported to exclusively produce and sell piglets for slaughter; these farms could be categorized as "breeding only". The remaining producers admitted selling both groups of animals, falling into a "farrow-to-finish" category.

Regarding animal husbandry, practices were dissonant amongst feeding, housing, and reproduction. Traditional feeding, in which commercial ration is completed with own-farm crops and products, was still present, even on larger holdings. In line with previous technical reports
(Outor-Monteiro et al., 2005; Fernandes et al., 2015), feeding substantially consisted of own-farm crops: cereals, harvested vegetables, tubers, and fruit. Most of the animals had access to pasture at some point, but boars and pregnant and dry sows mostly benefit from this practice. Inversely, the majority of lactating sows and piglets did not benefit from grazing, but rather were supplemented or had differentiated feed to fulfil their needs. On the other hand, housing seems to have changed over the last two decades. Carvalho (2000) reported all animals were kept in permanent stabling. Conversely, our study demonstrated that almost half of the producers have now their animals in permanent outdoor camping systems. Moreover, nearly all the producers have stated their animals have access to outside areas. Notwithstanding, there are still industrial and traditional piggeries used for housing the animals for great part of their production life. These systems had $16.8 \pm 2.3 \mathrm{~m}^{2}$ per breeding stock on average. This stocking density is well above the recommended stock density by EU directive (Council directive 2008/120/EC, 2009) (1.64$2.25 \mathrm{~m}^{2}$ per gilts and sows, respectively, when kept in groups of 6-39 animals), but the large variance registered could indicate some farms may be compromising stocking densities. In fact, two farms had indoor areas per breeding animal below $2 \mathrm{~m}^{2}$. Despite the contradictory reports from ANCSUB (2007), a third of producers claimed using farrowing crates.

Reproduction practices are generally poorer when compared with industrial pig production trends. Heat detection is not commonly used, suggesting that often the stud boar is kept in heterosexual groups. The use of artificial insemination is still incipient, and only one producer claimed to use boars from other farms; these two reproductive methods are important genetic diversity promoters and fundamental to a small population with a high inbreeding level as BP (Fernandes et al., 2010). On average, producers stated mating gilts for their first time 
between eight and nine months old. This is generally later than recommendations for industrial breeds and crossbreeds (6-7.5 months) (Tummaruk et al., 2001; Cottney et al., 2012; Dube et al., 2013) and earlier than other native European breeds in similar alternative rearing systems (910 months) (Petrovic et al., 2013; Karolyi et al., 2016).

Surgical castration of male piglets is still a common practice in the BP production system, even though producers who sell exclusively for roast piglet do not routinely perform the procedure. Only animals intended to be reared and sold for slaughter at older ages, for fresh or cured meat, were being castrated; piglets sold for roast piglet were not being subjected to the procedure. This tendency antagonizes with the rest of Portuguese industrial pork production, where most of males are kept entire (Thun et al., 2006; Fredriksen et al., 2009). Most of these

Table 2 - Descriptive statistics of feeding practices and housing conditions by type of farm

\begin{tabular}{|c|c|c|c|c|c|c|}
\hline & Units $^{1}$ & $\mathrm{R}$ & Total & Smallholders & Medium-sized farms & P-value ${ }^{2}$ \\
\hline \multicolumn{7}{|l|}{ Feeding } \\
\hline Proportion of ration used & & 57 & & & & 0.109 \\
\hline None & $\mathrm{n}(\%)$ & & $14(24.6)$ & $9(29.0)$ & $5(19.2)$ & \\
\hline$<50$ & n $(\%)$ & & $20(35.1)$ & $13(41.9)$ & $7(26.9)$ & \\
\hline $50-75$ & $\mathrm{n}(\%)$ & & $10(17.5)$ & $6(19.4)$ & $4(15.4)$ & \\
\hline$>75$ & n $(\%)$ & & $10(17.5)$ & $3(9.7)$ & $7(26.9)$ & \\
\hline 100 & $\mathrm{n}(\%)$ & & $3(5.3)$ & $0(0.0)$ & $3(11.5)$ & \\
\hline Differentiated feeding & & 58 & & & & 0.518 \\
\hline Yes & $\mathrm{n}(\%)$ & & $46(79.3)$ & $24(75.0)$ & $22(84.6)$ & \\
\hline No & $\mathrm{n}(\%)$ & & $12(20.7)$ & $8(25.0)$ & $4(15.4)$ & \\
\hline Automated feed/drinking systems & & 58 & & & & $<0.001$ \\
\hline None & n $(\%)$ & & $13(22.4)$ & $13(40.6)$ & $0(0.0)$ & \\
\hline Automated water troughs only & n $(\%)$ & & $34(58.6)$ & $17(53.1)$ & $17(65.4)$ & \\
\hline Automated water troughs and feeders & & & $11(19.0)$ & $2(6.3)$ & $9(34.6)$ & \\
\hline Grazing & & 57 & & & & 0.765 \\
\hline Yes & $\mathrm{n}(\%)$ & & $42(73.7)$ & $22(71.0)$ & $20(76.9)$ & \\
\hline No & $\mathrm{n}(\%)$ & & $15(26.3)$ & $9(29.0)$ & $6(23.1)$ & \\
\hline \multicolumn{7}{|l|}{ Housing } \\
\hline Housing system & & 57 & & & & 0.399 \\
\hline Industrial & $\mathrm{n}(\%)$ & & $4(7.0)$ & $2(6.5)$ & $2(7.7)$ & \\
\hline Traditional & n $(\%)$ & & $30(52.6)$ & $14(45.2)$ & $16(61.5)$ & \\
\hline Camping & $\mathrm{n}(\%)$ & & $23(40.4)$ & $15(48.4)$ & $8(30.8)$ & \\
\hline Forced ventilation & & 55 & & & & 0.035 \\
\hline Yes & $\mathrm{n}(\%)$ & & $10(18.2)$ & $2(6.9)$ & $8(30.8)$ & \\
\hline No & $\mathrm{n}(\%)$ & & $45(81.8)$ & $27(93.1)$ & $18(69.2)$ & \\
\hline Separation by production group & & 58 & & & & 0.495 \\
\hline Yes & $\mathrm{n}(\%)$ & & $49(84.5)$ & $26(81.3)$ & $23(88.5)$ & \\
\hline No & $\mathrm{n}(\%)$ & & $9(15.5)$ & $6(18.8)$ & $3(11.5)$ & \\
\hline Separation by gender & & 46 & & & & 0.205 \\
\hline Yes & $\mathrm{n}(\%)$ & & $13(28.3)$ & $5(20.0)$ & $8(38.1)$ & \\
\hline No & $\mathrm{n}(\%)$ & & $33(71.7)$ & $20(80.0)$ & $13(61.9)$ & \\
\hline Maternity system & & 52 & & & & 0.298 \\
\hline Farrowing crates with thermal insulation & $\mathrm{n}(\%)$ & & $18(34.6)$ & $8(26.7)$ & $10(45.5)$ & \\
\hline No farrowing crates/thermal insulation & $\mathrm{n}(\%)$ & & $20(38.5)$ & $12(40.0)$ & $8(36.4)$ & \\
\hline Outdoor cabins & n $(\%)$ & & $14(26.9)$ & $10(33.3)$ & $4(18.2)$ & \\
\hline Access to outside areas & & 58 & & & & 0.225 \\
\hline Yes & $\mathrm{n}(\%)$ & & $51(87.9)$ & $30(93.8)$ & $21(80.8)$ & \\
\hline No & n $(\%)$ & & $7(12.1)$ & $2(6.3)$ & $5(19.2)$ & \\
\hline \multirow[t]{3}{*}{ Total outdoor area (ha) } & & 51 & & & & 0.099 \\
\hline & Mean \pm SEM & & $3.1 \pm 0.9$ & $1.5 \pm 0.3$ & $5.3 \pm 1.9$ & \\
\hline & Median $[1 \mathrm{Q}, 3 \mathrm{Q}]$ & & $1[0.2,2.8]$ & $1[0.2,1.8]$ & $2[0.1,5]$ & \\
\hline \multirow[t]{3}{*}{ Total indoor area $\left(\mathrm{m}^{2}\right)$} & & 52 & & & & $<0.001$ \\
\hline & Mean \pm SEM & & $252.4 \pm 32.2$ & $129.1 \pm 16.3$ & $407.8 \pm 55.2$ & \\
\hline & Median [1Q, 3Q] & & $175[100,400]$ & $100[69,193]$ & $400[180,640]$ & \\
\hline
\end{tabular}

$\mathrm{R}$ - number of respondents; SEM - standard error of the mean.

${ }^{1}$ Non-normal data are presented as mean \pm SEM, median, first and third quartiles.

${ }^{2} \mathrm{P}$-value resulting from the independency test between smallholders and medium-sized farms. 
castrations are performed on piglets older than seven days $(83.3 \%)$, and smallholders usually perform them later. Informal conversations with producers suggest that this might be happening to facilitate the phenotypic selection of future breeding boars. It was not possible to determine whether the castrations were being performed by a qualified veterinarian or by the farmer. This should be highlighted on any subsequent study as EU regulations define that surgical castration on animals older than seven days should only be done under anaesthesia and prolonged analgesia by a veterinarian (Council directive 2008/120/EC, 2009). Although the UE directive 2008/120/EC restricts female spaying, undocumented reports from producers and workers also relate spaying gilts as a common practice, based on the assumption that cyclic ovarian function in sows will affect meat quality and, therefore, affect the acceptance of the final smoked-cured products. However, in this survey, only one producer admitted keeping this practice.
Feeding pigs with domestic leftovers is a potential risk to public and animal health. Despite EU regulations forbidding this type of practice (Regulation EC No. 1069/2009, 2009), a considerable high number of producers disclosed giving domestic food scraps to their animals in SH (25\%) and, to a lesser extent scale, on MS farms (17.3\%). These figures are higher than results from previous studies in other countries, where 1.5\% (Relun et al., 2015) and 8\% (Ribbens et al., 2008) of farmers reported feeding table scraps to their pigs. In sum, a significant number of irregular practices were reported by producers in both types of production system. This figure may have been even higher if a face-to-face interview had been conducted instead. Education should always be prioritized to mitigate this issue, altogether with strategic modernization of the reproductive management in BP production system.

Collected data evidenced some important differences between $\mathrm{SH}$ and $\mathrm{MS}$ farms; yet, production traits and

Table 3 - Descriptive statistics of reproduction practices by type of farm

\begin{tabular}{|c|c|c|c|c|c|c|}
\hline & Units $^{1}$ & $\mathrm{R}$ & Total & Smallholders & Medium-sized farms & P-value ${ }^{2}$ \\
\hline \multicolumn{7}{|l|}{ Reproduction } \\
\hline Heat detection & & 55 & & & & 0.777 \\
\hline Yes & $\mathrm{n}(\%)$ & & $19(34.5)$ & $11(37.9)$ & $8(30.8)$ & \\
\hline No & $\mathrm{n}(\%)$ & & $36(65.5)$ & $18(62.1)$ & $18(69.2)$ & \\
\hline Reproduction method & & 56 & & & & \\
\hline Natural with own boar & $\mathrm{n}(\%)$ & & $56(100.0)$ & $30(100.0)$ & $26(100.0)$ & 1 \\
\hline Natural with external boar & $\mathrm{n}(\%)$ & & $1(1.8)$ & $1(3.3)$ & $0(0.0)$ & 1 \\
\hline Artificial insemination & $\mathrm{n}(\%)$ & & $7(12.5)$ & $5(16.7)$ & $2(7.7)$ & 0.431 \\
\hline \multirow[t]{3}{*}{ Age at first service (months) } & & 53 & & & & 0.756 \\
\hline & Mean \pm SEM & & $8.5 \pm 0.2$ & $8.6 \pm 0.3$ & $8.5 \pm 0.4$ & \\
\hline & Median $[1 \mathrm{Q}, 3 \mathrm{Q}]$ & & $8[8,9]$ & $8[8,10]$ & $8[7,9]$ & \\
\hline Planned farrowing & & 57 & & & & 0.056 \\
\hline Yes & $\mathrm{n}(\%)$ & & $5(8.8)$ & $5(16.1)$ & $0(0.0)$ & \\
\hline No & $\mathrm{n}(\%)$ & & $52(91.2)$ & $26(83.9)$ & $26(100.0)$ & \\
\hline \multirow[t]{3}{*}{ Age at weaning (days) } & & 56 & & & & 0.155 \\
\hline & Mean \pm SEM & & $38.0 \pm 1.2$ & $39.6 \pm 1.7$ & $35.9 \pm 1.7$ & \\
\hline & Median $[1 \mathrm{Q}, 3 \mathrm{Q}]$ & & $35[30,45]$ & $38.5[30,45]$ & $35[30,40]$ & \\
\hline Voluntary waiting period & & 57 & & & & 0.031 \\
\hline Yes & $\mathrm{n}(\%)$ & & $9(15.8)$ & $8(25.8)$ & $1(3.8)$ & \\
\hline No & $\mathrm{n}(\%)$ & & $48(84.2)$ & $23(74.2)$ & $25(96.2)$ & \\
\hline Surgical castration & & 47 & & & & 0.426 \\
\hline Males only & $\mathrm{n}(\%)$ & & $28(59.6)$ & $14(56.0)$ & $14(63.6)$ & \\
\hline Males and females & $\mathrm{n}(\%)$ & & $1(2.1)$ & $0(0.0)$ & $1(4.5)$ & \\
\hline None & $\mathrm{n}(\%)$ & & $18(38.3)$ & $11(44.0)$ & $7(31.8)$ & \\
\hline \multirow[t]{3}{*}{ Age at castration (days) } & & 24 & & & & 0.037 \\
\hline & Mean \pm SEM & & $27.5 \pm 3.9$ & $36.2 \pm 6.2$ & $18.8 \pm 3.3$ & \\
\hline & Median $[1 \mathrm{Q}, 3 \mathrm{Q}]$ & & $29[9,35]$ & $33[19,56]$ & $19[7,30]$ & \\
\hline \multirow[t]{3}{*}{ Litters per sow per year } & & 57 & & & & 0.159 \\
\hline & Mean \pm SEM & & $2.0 \pm 0$ & $1.9 \pm 0.1$ & $2.1 \pm 0.1$ & \\
\hline & Median $[1 \mathrm{Q}, 3 \mathrm{Q}]$ & & $2[2,2]$ & $2[2,2]$ & $2[2,2]$ & \\
\hline \multirow[t]{3}{*}{ Litters per sow per lifetime } & & 43 & & & & \\
\hline & Mean \pm SEM & & $7.8 \pm 0.5$ & $7.7 \pm 0.8$ & $8.0 \pm 0.5$ & 0.781 \\
\hline & Median [Min, Max] & & $8[2,16]$ & $7[2,16]$ & $8[5,14]$ & \\
\hline
\end{tabular}

$\mathrm{R}$ - number of respondents; SEM - standard error of the mean.

${ }^{1}$ Normally distributed continuous variables are presented as mean \pm SEM, median, min and max. Non-normal data are presented as mean \pm SEM, median, first and third quartiles

${ }^{2} \mathrm{P}$-value resulting from the independency test between smallholders and medium-sized farms. 
practices varied much between holdings. This fact suggests a lack of organization between producers and might be in the origin of inconsistent products. In fact, uneven products constitute a great obstacle to reach new markets or to export, and it evidences an important weakness within the BP production system. Nevertheless, animal husbandry practices seem to have improved from previous reports, especially those related to housing. A significant proportion of Bísaro farms operate now on free-range systems, and most of them allow access to pasture. This important trait could be decisive when there is a growing market for informed consumers seeking for premium animal-friendly products.

\section{Conclusions}

The present study characterizes the Bísaro production system and increases our knowledge of traditional management practices of native pig breeds reared in alternative systems. It also supports future decisionmaking to improve the breed sustainability, considering the constrains raised by traditional practices now described.

Some of the practices acquired in this study reveal noncompliance with European Union regulations and must be revised, while others demonstrate variability within the production system and, therefore, should be discussed and delineated to enhance consistency of Bísaro products. Even though Bísaro farms can be typified into smallholders and medium-sized farms based on production, structure, automation and equipment, indoor areas, and reproductive management practices.

Bísaro conservation and sustained development should be prioritized to maximize animal production yields and profit of the producer, meeting the expectations of traditional cured meat production markets.

\section{Acknowledgments}

The authors wish to thank all producers, for their contribution, and ANCSUB and RuralBit, for their technical support. This study was sponsored by the Portuguese Science and Technology Foundation (FCT) under Projects UID/CVT/00772/2013 and UID/ CVT/00772/2016. Gustavo Paixão holds a PhD grant from the Animal Science Doctoral Program (AniSci), operation number NORTE-08-5369-FSE-000040, co-funded by the European Social Fund (FSE) and through National funds NORTE 2020 and Regional Operational Programme of North 2014/2020.

\section{References}

Alawneh, J. I.; Barnes, T. S.; Parke, C.; Lapuz, E.; David, E.; Basinang, V.; Baluyut, A.; Villar, E.; Lopez, E. L. and Blackall, P. J. 2014. Description of the pig production systems, biosecurity practices and herd health providers in two provinces with high swine density in the Philippines. Preventive Veterinary Medicine 114:73-87. https://doi.org/10.1016/j.prevetmed.2014.01.020

ANCSUB - Associação Nacional de Criadores de Suínos de Raça Bísara. 2007. A Raça Bísara. Available at: <http://www. porcobisaro.net/dados/racabisara.php $>$. Accessed on: Mar. 12, 2017

Araújo, J. P.; Amotim, I.; Santos Silva, J.; Pires, P. and Cerqueira, J. 2016. Outdoor housing systems for Bísaro pig breed with a hoop barn: some effects on welfare. p.87-91. In: Food futures: ethics, science and culture. Wageningen Academic Publisher, Porto.

Carolino, I.; Vicente, A.; Sousa, C. O. and Gama, L. T. 2007. SNaPshot based genotyping of the RYR1 mutation in Portuguese breeds of pigs. Livestock Science 111:264-269. https://doi.org/10.1016/j. livsci.2007.04.017

Carvalho, M. 2000. Nutrition and production systems of the "Bísaro" pig in the north-east region of Portugal. Options Méditerranéennes. Série A. Seminaires Méditerranéens. p.123-128.

Costa, H. M. G. 2015. Estudo prévio sobre a carcaça de suínos da Raça Bísara, de peso vivo de 10 a $65 \mathrm{~kg}$. Dissertação (M.Sc.). Instituto Politécnico de Bragança, Portugal.

Cottney, P. D.; Magowan, E.; Ball, M. E. E. and Gordon, A. 2012. Effect of oestrus number of nulliparous sows at first service on first litter and lifetime performance. Livestock Science 146:5-12. https://doi.org/10.1016/j.livsci.2012.02.013

Dube, B.; Mulugeta, S. D. and Dzama, K. 2013. Evaluating breeding objectives for sow productivity and production traits in Large White Pigs. Livestock Science 157:9-19. https://doi.org/10.1016/j. livsci.2013.06.018

Fernandes, A. J.; Fernandes, A.; Teixeira, A.; Leite, A.; Gonçalves, A.; Amorim, A.; Oliveira, A.; Alves, C.; Pereira, E.; Paulos, K.; Pereira, L. and Rodrigues, S. 2015. Porco Bísaro - Qualidade da carcaça e da carne. Quinta do Bísaro, Bragança, Portugal.

Fernandes, S. D.; Malovrh, S. and Kovac, M. 2010. Study of genetic diversity of bisaro pigs breed by pedigree analysis. Seria Zootehnie - Universitatea de Stiinte Agricole si Medicina Veterinara Ion Ionescu de la Brad 178:326-330.

Fredriksen, B.; Furnols, M. F. I.; Lundstrom, K.; Migdal, W.; Prunier, A.; Tuyttens, F. A. M. and Bonneau, M. 2009. Practice on castration of piglets in Europe. Animal 3:1480-1487. https://doi.org/10.1017/ S1751731109004674

Gelasakis, A. I.; Rose, G.; Giannakou, R.; Valergakis, G. E.; Theodoridis, A.; Fortomaris, P. and Arsenos, G. 2017. Typology and characteristics of dairy goat production systems in Greece. Livestock Science 197:22-29. https://doi.org/10.1016/j.livsci.2017.01.003

Hardigan, P.; Succar, C. and Fleisher, J. 2012. An analysis of response rate and economic costs between mail and web-based surveys among practicing dentists: a randomized trial. Journal of Community Health 37:383-394. https://doi.org/10.1007/s10900-011-9455-6

Karolyi, D.; Luković, Z.; Škorput, D.; Mahnet, Ž.; Klišanić, V.; Vnučec, I.; Salajpal, K. and Bošnjak, A. 2016. Morphological and reproductive traits of Turopolje pig breeding sows. p.47. In: 9th International Symposium on the Mediterranean Pig. Portalegre, Portugal.

Leslie, E. E.; Geong, M.; Abdurrahman, M.; Ward, M. P. and Toribio, J. A. 2015. A description of smallholder pig production systems in eastern Indonesia. Preventive Veterinary Medicine 118:319-327. https://doi.org/10.1016/j.prevetmed.2014.12.006 
Outor-Monteiro, D.; Mestre, R. B.; Fontes, A. S. and Azevedo, J. T. 2005. A raça suína Bísara. Minerva Transmontana, Vila Real, Portugal.

Petrovic, M.; Savic, R.; Parunovic, N.; Radojkovic, D. and Radovic, C. 2013. Reproductive traits of pigs of Mangalitsa breed. Acta Argiculturae Slovenica 4:89-92.

Ramos, A. M.; Mestre, R.; Gouveia, S.; Evans, G.; Zhang, Y.; Cardoso, A.; Rothschild, M.F.; Plastow, G. and Rangel-Figueiredo, T. 2003. Use of Type I DNA markers for initial genetic characterization of two Portuguese swine breeds. Archivos de Zootecnia 52:255-264.

Relun, A.; Charrier, F.; Trabucco, B.; Maestrini, O.; Molia, S.; Chavernac, D.; Grosbois, V.; Casabianca, F.; Etter, E. and Jori, F. 2015. Multivariate analysis of traditional pig management practices and their potential impact on the spread of infectious diseases in Corsica. Preventive Veterinary Medicine 121:246-256. https://doi.org/10.1016/j.prevetmed.2015.07.004

Ribbens, S.; Dewulf, J.; Koenen, F.; Mintiens, K.; De Sadeleer, L.; Kruif, A. and Maes, D. 2008. A survey on biosecurity and management practices in Belgian pig herds. Preventive Veterinary Medicine 83:228-241. https://doi.org/10.1016/j. prevetmed.2007.07.009

Riedel, S.; Schiborra, A.; Hülsebusch, C. and Schlecht, E. 2014. The productivity of traditional smallholder pig production and possible improvement strategies in Xishuangbanna, South Western China. Livestock Science 160:151-162. https://doi.org/10.1016/ j.livsci.2013.11.009

Santos e Silva, J.; Bernardo, A. and Pires da Costa, J. 2000a. Genetic characterization and inventory of the Bísaro pig through visible effect genes. Their utilization in the genotypic comparison between populations and in the establishing of a nucleus for in vivo genetic conservation. Options Méditerranéennes. Série A, Séminaires Méditerranéens 41:39-51.
Santos e Silva, J.; Ferreira-Cardoso, J.; Bernardo, A. and Pires da Costa, J. S. 2000b. Conservation and development of the Bísaro pig. Characterisation and zootechnical evaluation of the breed for production and genetic management. p.83-92. In: Quality of meat and fat in pigs as affected by genetics and nutrition. EAAP, Zurich, Switzerland.

Santos Silva, J. and Tirapicos Nunes, J. L. 2013. Inventory and characterization of traditional Mediterranean pig production systems. Advantages and constraints towards its development. Acta Agriculturae Slovenica Supplement 4:61-67.

Schembri, N.; Hernandez-Jover, M.; Toribio, J. A. L. M. L. and Holyoake, P. K. 2015. On-farm characteristics and biosecurity protocols for small-scale swine producers in eastern Australia. Preventive Veterinary Medicine 118:104-116. https://doi.org/ 10.1016/j.prevetmed.2014.11.008

Shih, T. and Fan, X. 2007. Response rates and mode preferences in web-mail mixed-mode surveys: a meta-analysis. International Journal of Internet Science 2:59-82.

Thun, R.; Gajewski, Z. and Janett, F. 2006. Castration in male pigs: techniques and animal welfare issues. Journal of Physiology and Pharmacology 57(Suppl 8):189-94.

Tummaruk, P.; Lundeheim, N.; Einarsson, S. and Dalin, A. M. 2001. Effect of birth litter size, birth parity number, growth rate, backfat thickness and age at first mating of gilts on their reproductive performance as sows. Animal Reproduction Science 66:225-237. https://doi.org/10.1016/S0378-4320(01)00095-1

Vicente, A. A.; Carolino, M. I.; Sousa, M. C. O.; Ginja, C.; Silva, F. S.; Martinez, A. M.; Vega-Pla, J. L.; Carolino, N. and Gama, L. T. 2008. Genetic diversity in native and commercial breeds of pigs in Portugal assessed by microsatellites. Journal of Animal Science 86:2496-2507. https://doi.org/10.2527/jas.2007-0691 